\title{
STUDY ON MAJOR PESTICIDES AND FERTILIZERS USED IN NEPAL
}

\author{
Jasmine Diwakar*, Tista Prasai*, Shankar Raj Pant* and Bina Laxmi Jayana** \\ *Nepal Academy of Science and Technology, Khumultar, Lalitpur, Nepal. \\ **Central Department of Microbiology, Tribhuvan University, Kathmandu, Nepal.
}

\begin{abstract}
The data of Nepal Government shows that nine major pesticides groups with seven subgroups of Insecticides were imported from the year 1997 to 2003. The pesticide use amounts to $142 \mathrm{~g} /$ ha which is low compared to other counties. The highest pesticides quantity imported \& quantity consumed from the 2056/57 (1999) to 2060/061(2003) were fungicides, bactericides, acaricides \& seed treatment. group. For the year 2056/57 (1999) \& 2057/58(2000), no import \& consumption of biopesticides were done but from the year 2058/59(2001) to 2060/061(2003) no import \& consumption of plant regulators was done. The various types of pesticides with 306 trade names and 71 technical names are registered / enlisted and used in Nepal which includes Insecticides, Fungicides, Herbicides, Rodenticides, Acaricides and Others. Moreover, twelve types of pesticides are band in Nepal for its import and use. Similarly, the demand of fertilizers were increased from 1997/98 to 2001/02 and then decreased dramatically with high amount from 2001/02 to 2002/03 and since then again it again increased up to 204/05. This trend is same for Urea and Diammonium Phoshphate whereas Murate of Potash is increasing from 1997/98 to 2004/04. Seven types of fertilizers are being used in Nepal viz. Urea, Diammonium Phosphate (DAP), Murate of Potash (MOP), Ammonium Sulphate (AS), Single Super Phosphate (SSP), Ammonium Phosphate Sulphate (APS) and NPK. These are imported by Public institution like Agricultural Input Corporation (AIC), Private Institutions and also donated/granted by the Government of Japan called as 2KR (Two Kenny Round). The import of fertilizers shows irregular trend. The import of fertilizers was highest in 1998/99 which amounted to 219038 metric ton and since then it decreased although there showed fluctuations. The distribution of fertilizers was increase from 1997/98 and reached highest in the year 2002/03 and since then it started decreasing. Similarly, the fertilizer consumption was highest in the year 1994/95 which was $30.4 \mathrm{~kg} / \mathrm{ha}$ which declined since then and showed fluctuation. The fertilizer consumption is regularly decreasing in the recent years from the year 2002/03.
\end{abstract}

Key words: Agriculture; Fertilizer; Insecticide; Pest and pesticide.

\section{INTRODUCTION}

A pest is any species that competes with the us/plants for food, invades lawns and gardens, destroys wood in houses, spreads disease, or is simply a nuisance. Worldwide, some 10,000 species of insects attack crops, whose yields are also reduced by about 1800 species of weeds and some 80,000 100,000 plant diseases caused by bacteria, viruses, fungi, and algae. In natural ecosystems and many polyculture agroecosystems, natural enemies (predators, parasites and disease organisms) control the populations of 50-90\% of pest species, a crucial type of earth capital. However we have upset the natural balance and we need the device to protect our monoculture. This purpose is served using pesticides. Pesticides are the chemicals to kill organisms which we consider undesirable. Common types of pesticides are insecticides (insect - killer), herbicides/ weedicide (weed-killer), fungicide (fungi-killer), nematocide (nemates killer) and rodenticide (rodent - killer) (Miller 2002). According to Pesticide Act, 1991 "Pesticides means the poisonous medicines used for killing or destroying the harmful pests that appear in seeds, plants, trees, animals, fowls etc.”

Before World War II, pest control in agriculture was mainly based on sound agronomy. Pesticides were used only occa- sionally, and were simple chemicals such as copper or sulfur, or derivatives of plants such as tobacco, neem or pyrethrins (Pyrethrins are naturally occurring and are based on the pyrethrum plant). Discovery of DDT in 1938 by Paul Muller won a Nobel Prize used in WWII for mosquito (malaria and Yellow Fever) control. After the war, the chemical industry expanded their use in agriculture. However, pesticides boomed during and after WWII (Palikhe 2006).

Synthetic pesticides spearheaded by DDT and BHC got introduced to Nepalese agriculture and public health during 1995. from then onwards their issue increased both on quantity and diversification in terms of newer synthetic pesticides. At that time, the general awareness on environment issues was so minimal and people were not told adequately about the hazardous aspect of the pesticides. People just saw their miraculous effect on malaria and the pests. However, the longterm effect on human health and environment was invisible. People started to call pesticide a medicine. The introduction of new high yielding varieties, intensification and commercialization of crop production, continuous crop growing and the improved access to markets brought about major changes in plant protection (Palikhe 2006). Appropriate crop protection methods became a very important factor for productivity and production of crops. Farmers, particularly in areas of com-

Author for Correspondence: Jasmine Diwakar, Nepal Academy of Science and Technology, Khumultar, Lalitpur, Nepal. Email: jasdiwa@gmail.com 
Table 1: Pesticides Import and Consumption Data 1999-2003 (in Agriculture and Public Health)

\begin{tabular}{|c|c|c|c|c|c|c|c|c|c|c|c|}
\hline & & $2056 / 57(1999)$ & & $2057 / 58(2000)$ & & 2058/59(2001) & & $2059 / 60(2002)$ & & $2066 / 61(2003)$ & Remarks \\
\hline \multirow[t]{3}{*}{ Item } & Quantity & Quantity & Quantity & Quantity & Quantity & Quantity & Quantity & Quantity & Quantity & Quantity & \\
\hline & imported & consumed & imported & consumed & imported & consumed & imported & consumed & imported & consumed & \\
\hline & a. I. (kg) & a. I. (kg) & a. I. (kg) & a. I. (kg) & a. I. (kg) & a. I. (kg) & a. I. (kg) & a. I. (kg) & a. I. (kg) & a. I. (kg) & \\
\hline Organochlorines & 9969.4 & 9200.1 & 9716 & 8853.6 & 10006.5 & 9752.05 & 7369.25 & 7484.05 & 4339 & 4478.65 & \\
\hline Organophosphates & 29067.45 & 23303.27 & 41715.4 & 35630.12 & 40747.95 & 43413.52 & 41704.7 & 39507.58 & 70203 & 72400.12 & \\
\hline Synthetic & 3713.45 & 2882 & 6542.76 & 5876.56 & 7949.87 & 8294.53 & 9865.96 & 9461.028 & 7060 & 7464.93 & \\
\hline \multicolumn{12}{|l|}{ Pyrethroids } \\
\hline Carbamates & 284.25 & 243.99 & 633.45 & 648.18 & 696.6 & 688.71 & 576 & $\begin{array}{l}456.38 \\
\end{array}$ & 3306.9 & 3426.52 & \\
\hline Mixed Insecticides & 430 & 353.35 & 3801.3 & 3750.18 & 923.02 & 943.54 & 874.75 & 815.5 & 702 & 761.25 & \\
\hline others Insecticides & 3688.78 & 3622.78 & 12481.7 & 12454.38 & 2827.2 & 2747.17 & 18546.1 & 14168.55 & 9926 & 14303.57 & pesticide \\
\hline Total Insecticides & 47153.33 & 39605.49 & 74920.6 & 67213.02 & 63151.14 & 65839.52 & 78936.8 & 71893.088 & 95536.9 & 102835 & consumed \\
\hline $\begin{array}{l}\text { Fungicides, } \\
\text { Bactericides }\end{array}$ & 54530.66 & 53330.49 & 102773 & 94917.98 & 75444.88 & 82994.45 & 90570.4 & 65584.24 & 55590.8 & 55590.8 & in $2003=$ \\
\hline acaricides and seed & & & & & & & & & & & pesticide \\
\hline treatments & & & & & & & & & & & imported \\
\hline Herbicides & 2678.8 & 2377.02 & 14943.4 & 10860.4 & 3258.84 & 6888.57 & 6843.9 & 6217.02 & 11239 & 11865.88 & in $2003+$ \\
\hline Rodenticides & 4064.4 & 3339.6 & 3420 & 2908 & 4297.6 & 4161.6 & 1240 & 1628 & 7868 & 7480 & Remaining \\
\hline Plant Growth Regulators & 0.63 & 0.58 & 7.6 & 7.6 & 0 & 0 & 0 & 0 & 0 & 0 & stocks \\
\hline Bio-pesticides & 0 & 0 & 0 & 0 & 0.02 & 0.02 & 0.06 & 0.06 & 1.71 & 1.71 & of 2002 \\
\hline Others & & & & & & & & & 6136.4 & 6136.4 & \\
\hline Total & 108427.82 & 98653.18 & 196065 & 175907 & 146152.5 & 159884.16 & 177591 & 145322.41 & 176373 & 183909.8 & \\
\hline
\end{tabular}

mercial vegetables production, are primarily relying on chemical pest control methods. Pesticides are not as extensively used in Nepal as on other countries in Asia in terms of the ratio of active ingredients used per hectare of cropland. The characteristics of Nepalese pesticide use in terms of location, intensity, target crops, types of chemicals and trends, however, point to some disturbing issues. The pesticide consumption is increasing by about $10-20 \%$ per year and pesticide expenses in market oriented vegetables and fruit production in Nepal is a major cost factor. According to PPD report from 2003 the annual pesticide consumption comprises of $41 \%$ insecticides, 51.8\% fungicides, 7.2\% others. Agriculture and health imports of 2001 is almost US\$2.03 million of chemical pesticides (PPD 2003). Farmers in general are applying pesticides in crop fields inefficiently and using traditional method in rice field and also overdoses in vegetables and pollution of the environment as a whole. Awareness and skill regarding safety and efficient application of pesticides is not adequate at farmers' level. These can be upgraded to a great extent by providing training to the farmers on the concept of integrated pesticide and pest management. (Palikhe 2006). Various types of pesticides and fertilizers are used in Nepal. The use of pesticides and fertilizers in Nepal is increasing. To meet the food demand of the nation, the productivity of the agriculture should be increased. For this, the pesticides and fertilizers should be used in adequate amount. However, the pesticides use of 142 grams/ hectares is very low in compared to other countries.

\section{OBJECTIVES:}

i. To know the various types of pesticides and fertilizers use in Nepal.

ii. To know the quantity of pesticides and fertilizers used in Nepal.

iii. To know the yearly trend of pesticides and fertilizers use in Nepal.

\section{MATERIALS AND METHODS:}

Various information, data and status of pesticides use in Nepal was collected from Pesticides Registration and Management
Table 2: Pesticides consumption in Nepal 2003

\begin{tabular}{|c|c|c|}
\hline \multicolumn{2}{|c|}{ Kinds of pesticide } & \multirow{2}{*}{$\begin{array}{l}\text { Quantity of Active } \\
\text { Ingredient in Kg. }\end{array}$} \\
\hline A. & AGRICULTURAL PESTICIDES & \\
\hline 1 & INSECTICIDES & \\
\hline 1.1 & Organochlorine(Endosulfan) & 4478.65 \\
\hline 1.2 & $\begin{array}{l}\text { Organo-phosphates(Acephate, } \\
\text { Chlorpyriphos, Quinalphos, Dichlorovos, } \\
\text { Phorate etc.) }\end{array}$ & 72400.12 \\
\hline 1.3 & Carbamates & 3426.52 \\
\hline 1.4 & $\begin{array}{l}\text { Synthetic Pyrethroids (Alphametrin, } \\
\text { Cypermethrin, Fenvalerate, Deltamethrin, } \\
\text { etc.) }\end{array}$ & 7214.93 \\
\hline 1.5 & Botanical products (Azadiractin) & 50 \\
\hline 1.6 & $\begin{array}{l}\text { Mixed insecticides (Chlor } \\
\text { pyriphos+Cypermethrin, } \\
\text { Alphamethrin+Chlopyriphos, } \\
\text { Quinalphos+Cypermethrin, etc.) }\end{array}$ & 761.25 \\
\hline 1.7 & $\begin{array}{l}\text { Others(Aluminiumphosphide, } \\
\text { Cartaphydrochloride, Imidacloprid } \\
\text {,Propagite, Ethofenox, Fenpropathrin, } \\
\text { Fipronil etc.) }\end{array}$ & 14253.57 \\
\hline \multicolumn{2}{|c|}{ TOTAL INSECTICIDE } & 102585.04 \\
\hline 2 & $\begin{array}{l}\text { HERBICIDES (Glyphodphate 2, 4-D, } \\
\text { Butachlor, etc.) }\end{array}$ & 11865.88 \\
\hline 3 & FUNGICIDES & 55199 \\
\hline 4 & PLANT GROWTH REGULATORS & 0 \\
\hline 5 & RODENTICIDES & 7480 \\
\hline 6 & BIO-PESTICIDES (Bt, NPV, etc.) & 1.71 \\
\hline 7 & ACARICIDES & 346 \\
\hline 8 & BACTERICIDES & 45.8 \\
\hline 9 & $\begin{array}{l}\text { OTHERS (Metaldehydes, Chloroflurazon, } \\
\text { etc.) }\end{array}$ & 6136.4 \\
\hline A. & SUB-TOTAL ( Agri pesticides) & 183659.83 \\
\hline B. & $\begin{array}{l}\text { PESTICIDES USED IN PUBLIC } \\
\text { HEALTH (Alphacypermethrin) }\end{array}$ & 250 \\
\hline \multicolumn{2}{|c|}{ GRAND TOTAL(A+B) } & 183909.83 \\
\hline
\end{tabular}

Note: Pesticide consumed in 2003=pesticide imported in 2003+ Remaining stocks of 2002

(Source: Pesticides registration and management section of Ministry of Agriculture and Cooperatives. 2062) 
Table 3: Description of Enlisted/registered Pesticides

\begin{tabular}{|l|l|l|l|}
\hline SN & Kinds of pesticides & Commercial Name & Common Name \\
\hline 1 & Insecticides & 210 & 40 \\
\hline 2 & Fungicides & 64 & 18 \\
\hline 3 & Herbicides & 18 & 5 \\
\hline 4 & Rodenticides & 9 & 3 \\
\hline 5 & Acricides & 1 & 1 \\
\hline 6 & Others & 4 & 4 \\
\hline & Total & $\mathbf{3 0 6}$ & $\mathbf{7 1}$ \\
\hline
\end{tabular}

(Source: Pesticides registration and management section of Ministry of Agriculture and Cooperatives. 2062)

Table 4: List of pesticides band in Nepal

\begin{tabular}{|l|l|l|}
\hline SN & Name of Pesticides & Remarks \\
\hline 1. & Chlordane & Persistent Organic Pollutant Pesticides \\
\hline 2. & DDT & Persistent Organic Pollutant Pesticides \\
\hline 3. & Dieldrin & Persistent Organic Pollutant Pesticides \\
\hline 4. & Aldrin & Persistent Organic Pollutant Pesticides \\
\hline 5. & Aldrin & Persistent Organic Pollutant Pesticides \\
\hline 6. & Heptachlor & Persistent Organic Pollutant Pesticides \\
\hline 7. & Methyle Parathion & \\
\hline 8. & Mirex & Persistent Organic Pollutant Pesticides \\
\hline 9. & Monocrotophos & \\
\hline 10. & Toxafen & Persistent Organic Pollutant Pesticides \\
\hline 11. & BHC & \\
\hline 12. & Lindane & \\
\hline 13. & Phosphamidane & \\
\hline 14. & Organo Mercuty & \\
\hline
\end{tabular}

(Source: Pesticides registration and management section of Ministry of Agriculture and Cooperatives. 2062)
Table 5: Demand (APPs estimate) (in metric tones)

\begin{tabular}{|l|l|l|l|l|}
\hline \multicolumn{1}{|c|}{ Year } & \multicolumn{1}{c|}{ Urea } & \multicolumn{1}{c|}{ DAP } & \multicolumn{1}{c|}{ MOP } & \multicolumn{1}{c|}{ Total } \\
\hline $1997 / 98$ & 144142 & 61978 & 2690 & 208810 \\
\hline $1998 / 1999$ & 163491 & 70298 & 3051 & 236840 \\
\hline $1999 / 000$ & 185437 & 79734 & 3460 & 268631 \\
\hline $2000 / 01$ & 210329 & 90438 & 3925 & 304692 \\
\hline $2001 / 02$ & 238562 & 102577 & 4451 & 345590 \\
\hline $2002 / 03$ & 148488 & 76087 & 8000 & 232575 \\
\hline $2003 / 04$ & 164178 & 80435 & 9000 & 253613 \\
\hline $2004 / 05$ & 179112 & 97826 & 10000 & 286938 \\
\hline
\end{tabular}

(Source: Fertilizer Unit of Ministry of Agriculture and Cooperatives. 2062)

Section of Ministry of Agriculture and Cooperatives (Nepal Government). Similarly, the information, data and status of fertilizers use in Nepal was collected from Fertilizer Unit of Ministry of Agriculture and Cooperatives (Nepal Government). Thus obtained secondary data was analyzed.

\section{RESULTS:}

(Table 1 - 4)

\section{Fertilizers:}

(Table 5 - 10)

\section{DISCUSSION:}

From the government data of Pesticides, it is found that 9 major pesticides groups with 7 subgroups of Insecticides were

Table 6: Import of Fertilizers (APP's Estimate) (in metric tones)

\begin{tabular}{|c|c|c|c|c|c|c|c|c|c|c|}
\hline \multicolumn{2}{|l|}{ Year } & $1997 / 98$ & 1998/1999 & $1999 / 000$ & $2000 / 01$ & 2001/02 & 2002/03 & 2003/04 & $2004 / 05$ & Total \\
\hline \multirow{2}{*}{$\begin{array}{l}\text { Public } \\
\text { (AIC) }\end{array}$} & Urea & 49660 & 77857 & 30000 & 24189 & $N A$ & $N A$ & 4134 & 5370 & 191210 \\
\hline & $D A P$ & 10000 & 50132 & 10000 & 30415 & 12500 & $N A$ & 7000 & 12081 & 132128 \\
\hline \multirow[b]{7}{*}{ Private } & Urea & 17550 & 91049 & 61347 & 76454 & 79350 & 45190 & 96146 & 17161 & 484147 \\
\hline & $D A P$ & $N A$ & $N A$ & 31173 & 12365 & 21004 & 28187 & 29399 & 30726 & 152854 \\
\hline & $M O P$ & $N A$ & $N A$ & $N A$ & $N A$ & $N A$ & $N A$ & 1100 & 135 & 1235 \\
\hline & AS & $N A$ & NA & $N A$ & $N A$ & 3000 & 6662 & 4639 & 4689 & 18989 \\
\hline & SSP & $N A$ & $N A$ & $N A$ & $N A$ & $N A$ & 3400 & 1498 & 500 & 5398 \\
\hline & $\begin{array}{l}\text { NPK } \\
\text { 12:32:16 }\end{array}$ & $N A$ & $N A$ & $N A$ & $N A$ & $N A$ & $N A$ & 500 & $N A$ & 500 \\
\hline & APS & $N A$ & $N A$ & $N A$ & $N A$ & $N A$ & $N A$ & 4666 & 11747 & 16413 \\
\hline \multirow[b]{4}{*}{ 2KR } & Urea & 11440 & $N A$ & 7000 & 11800 & 16220 & 17830 & 7715 & $N A$ & 72025 \\
\hline & $D A P$ & $N A$ & $N A$ & 14817 & 10920 & 13820 & 10255 & 9500 & $N A$ & 59312 \\
\hline & $M O P$ & $N A$ & $N A$ & $N A$ & 5140 & 4300 & $N A$ & $N A$ & $N A$ & 9440 \\
\hline & AS & $N A$ & $N A$ & 1500 & $N A$ & $N A$ & $N A$ & $N A$ & $N A$ & 1500 \\
\hline \multirow[b]{7}{*}{ Total } & Urea & 78650 & 168906 & 98347 & 112363 & 95570 & 63020 & 107995 & 22531 & 747382 \\
\hline & $D A P$ & 10000 & 50132 & 55990 & 53700 & 47324 & 38442 & 45899 & 42807 & 344294 \\
\hline & $M O P$ & $N A$ & $N A$ & $N A$ & 5140 & 4300 & $N A$ & 1100 & 135 & 10675 \\
\hline & $A S$ & $N A$ & $N A$ & 1500 & $N A$ & 3000 & 6662 & 4639 & 4689 & 20489 \\
\hline & SSP & $N A$ & $N A$ & $N A$ & $N A$ & $N A$ & 3400 & 1498 & 500 & 5398 \\
\hline & $N P K$ & $N A$ & $N A$ & $N A$ & $N A$ & $N A$ & $N A$ & 500 & $N A$ & 500 \\
\hline & APS & $N A$ & $N A$ & $N A$ & $N A$ & $N A$ & $N A$ & 4666 & 11747 & 16413 \\
\hline \multicolumn{2}{|c|}{ Grand Total } & 88650 & 219038 & 155837 & 171203 & 150194 & 111524 & 166297 & 82409 & 1145151 \\
\hline
\end{tabular}

(Source: Fertilizer Unit of Ministry of Agriculture and Cooperatives. 2062) 
Table 7: Distribution of fertilizers in Nepal (in metric tones)

\begin{tabular}{|c|c|c|c|c|c|c|c|c|c|c|}
\hline \multicolumn{2}{|c|}{ Year/ Fertilizers } & \multirow{2}{*}{$\begin{array}{l}\mathbf{1 9 9 7 / 9 8} \\
59110\end{array}$} & \multirow{2}{*}{$\begin{array}{l}\mathbf{1 9 9 8 / 1 9 9 9} \\
59956\end{array}$} & \multirow{2}{*}{$\begin{array}{l}\mathbf{1 9 9 9 / 0 0} \\
43508\end{array}$} & \multirow{2}{*}{$\begin{array}{l}\mathbf{2 0 0 0 / 0 1} \\
29528\end{array}$} & \multirow{2}{*}{$\begin{array}{l}\mathbf{2 0 0 1 / 0 2} \\
15939\end{array}$} & \multirow{2}{*}{$\begin{array}{l}\mathbf{2 0 0 2 / 0 3} \\
34432 \\
\end{array}$} & \multirow{2}{*}{$\begin{array}{l}\text { 2003/04 } \\
8519 \\
\end{array}$} & \multirow{2}{*}{$\begin{array}{l}\mathbf{2 0 0 4 / 0 5} \\
10753 \\
\end{array}$} & \multirow{2}{*}{$\begin{array}{l}\text { Total } \\
261745 \\
\end{array}$} \\
\hline & Urea & & & & & & & & & \\
\hline & DAP & 28530 & 26298 & 26156 & 15633 & 21249 & 33330 & 10522 & 19881 & 181599 \\
\hline \multirow[b]{2}{*}{ Public } & MOP & 3538 & 2096 & 308 & 58 & 956 & 2966 & 1681 & 2409 & 14012 \\
\hline & AS & NA & NA & 1490 & NA & NA & NA & NA & NA & 1490 \\
\hline \multirow[b]{9}{*}{ Private } & Urea & 17550 & 68477 & 61797 & 67569 & 62217 & 69029 & 75804 & 41246 & 463689 \\
\hline & DAP & NA & NA & 14930 & 23847 & 27590 & 23708 & 35157 & 18150 & 143382 \\
\hline & MOP & NA & NA & NA & 1 & 300 & 671 & 709 & 335 & 2016 \\
\hline & AS & NA & NA & NA & NA & 1970 & 4348 & 6095 & 5291 & 17704 \\
\hline & SSP & NA & NA & NA & NA & NA & 2327 & 1741 & 1559 & 5627 \\
\hline & APS & NA & NA & NA & NA & NA & NA & 1280 & 10170 & 11450 \\
\hline & $\begin{array}{l}\text { NPK } \\
\text { 12:32:16 }\end{array}$ & NA & NA & NA & NA & NA & NA & 500 & NA & 500 \\
\hline & $20: 20$ & NA & NA & NA & NA & NA & 3359 & 14408 & 10670 & 28436 \\
\hline & 20:20:10 & NA & NA & NA & NA & NA & 199 & 661 & 2242 & 3102 \\
\hline \multirow[b]{10}{*}{ Total } & Urea & 76660 & 128433 & 105305 & 97097 & 78156 & 103461 & 84323 & 51999 & 725434 \\
\hline & DAP & 28530 & 26298 & 41086 & 39480 & 48839 & 57038 & 45679 & 38031 & 324981 \\
\hline & MOP & 3538 & 2096 & 308 & 59 & 1256 & 3637 & 2391 & 2744 & 16029 \\
\hline & AS & NA & NA & 1490 & NA & 1970 & 4348 & 6095 & 5291 & 19194 \\
\hline & SSP & NA & NA & NA & NA & NA & 2327 & 1741 & 1559 & 5627 \\
\hline & APS & NA & NA & NA & NA & NA & NA & 1280 & 10170 & 11450 \\
\hline & $\mathrm{NPK}^{*}$ & NA & NA & NA & NA & NA & NA & 500 & NA & 500 \\
\hline & $20: 20$ & NA & NA & NA & 9559 & 9718 & 3359 & 14408 & 10670 & 47714 \\
\hline & 20:20:10 & NA & NA & NA & 10 & 153 & 199 & 660.9 & 2242 & 3265 \\
\hline & 18:18:10 & NA & NA & NA & 160 & 400 & NA & NA & NA & 560 \\
\hline \multicolumn{2}{|c|}{ Grand Total } & 108728 & 156827 & 148189 & 146365 & 140492 & 174369 & 157077 & 122706 & 1154754 \\
\hline
\end{tabular}

NPK* 1:32:16 Fertilizers like 20: 20: 0, 20:20:10, 18:18:10 grades are produced from mixing and blending companies in Nepal.

(Source: Fertilizer Unit of Ministry of Agriculture and Cooperatives. 2062)

imported from the year 1997 to 2003 . As shown by table 1, Fungicides, Bactericides, Acaricides and seed treatment group of pesticides were imported in highest quantity in the year 1998 to 2002 whereas the organophosphates were imported highest quantity in the year 1997 and 2003. It was observed that the Biopesticides were imported in smallest quantity and their quantities are shown only after 2003 in table 1 with the smallest investment. The highest pesticides quantity imported \& quantity consumed from the 2056/57 (1999) to 2060/ 061(2003) were fungicides, bactericides, acaricides \& seed treatment. group. For the year 2056/57 (1999) \& 2057/58(2000), no import \& consumption of bio-pesticides were done but from the year 2058/59(2001) to 2060/061(2003) no import \& consumption of plant regulators was done.

The table 2 shows that particularly in the 2003, insecticides were consumed in the year 2003 which includes organochlorines, organophosphates, carbamates, synthetic pyrethroids, botanical products mixed insecticides and others. This quantity amounts to $102585.04 \mathrm{~kg}$. However, the consumption of plant growth regu- lators were shown as $0.00 \mathrm{~kg}$ which means the value may be in insignificant quantity or its consumption were nil. Except this, biopesticides were consumed in least amount i.e.1.71 kg.

The table 3 shows that various types of pesticides with 306 trade names and 71 technical names are registered/ enlisted and used in Nepal which includes Insecticides, Fungicides, Herbicides, Rodenticides, Acaricides and Others. As shown in the table 4, fourteen types of pesticides are band in Nepal for its import and use.

As shown in table 5, the demand of fertilizers were increased from 1997/98 to 2001/02 and then decreased dramatically with high amount from 2001/02 to 2002/03 and since then again it again increased up to 204/05. This trend is same for Urea and DAP whereas MOP is increasing from 1997/98 to 2004/04.

Seven types of fertilizers are being used in Nepal viz. Urea, Diammonium Phosphate (DAP), Murate of Potash (MOP), Ammonium Sulphate (AS), Single Super Phosphate (SSP), Ammonium Phosphate Sulphate (APS) and NPK. These are imported by Public institution like Agricultural Input Corpo- 
Table 8: Consumption of fertilizers in Nepal

\begin{tabular}{|l|l|l|l|l|l|l|l|l|}
\hline Year & $\mathrm{N}$ & $\mathrm{P}$ & $\mathrm{K}$ & Total & Kg/ha & Ratio of nutrients & & \\
\hline & & & & & & $\mathrm{N}$ & $\mathrm{P}$ & $\mathrm{K}$ \\
\hline $1994 / 95$ & 64385 & 24300 & 1578 & 90263 & 30.41 & 1 & 0.38 & 0.025 \\
\hline $1997 / 98$ & 40399 & 13124 & 2123 & 55646 & 18.75 & 1 & 0.32 & 0.053 \\
\hline $1998 / 99$ & 63813 & 12097 & 1258 & 77168 & 26 & 1 & 0.19 & 0.02 \\
\hline $1999 / 00$ & 55836 & 18900 & 185 & 74921 & 25.24 & 1 & 0.34 & 0.003 \\
\hline $2000 / 01$ & 54453 & 20526 & 20 & 74999 & 25.27 & 1 & 0.38 & 0.0004 \\
\hline $2001 / 02$ & 47005 & 24512 & 809 & 72326 & 24.37 & 1 & 0.52 & 0.017 \\
\hline $2002 / 03$ & 49484 & 27321 & 2202 & 89007 & 29.99 & 1 & 0.46 & 0.037 \\
\hline $2003 / 04$ & 51620 & 24721 & 1581 & 77922 & 26.25 & 1 & 0.48 & 0.031 \\
\hline $2004 / 05$ & 36493 & 22360 & 1871 & 60723 & 19.65 & 1 & 0.61 & 0.051 \\
\hline
\end{tabular}

(Source: Fertilizer Unit of Ministry of Agriculture and Cooperatives. 2062)

Table9: \% contribution in import of fertilizers

\begin{tabular}{|l|c|c|c|c|}
\hline Year & AIC & Private & 2KR & Total \\
\hline $1997 / 98$ & 67 & 20 & 13 & 100 \\
\hline $1998 / 99$ & 58 & 42 & 0 & 100 \\
\hline $1999 / 00$ & 26 & 59 & 15 & 100 \\
\hline $2000 / 01$ & 32 & 52 & 16 & 100 \\
\hline $2001 / 02$ & 8 & 69 & 23 & 100 \\
\hline $2002 / 03$ & & 75 & 25 & 100 \\
\hline $2003 / 04$ & 7 & 83 & 10 & 100 \\
\hline $2004 / 05$ & 21 & 79 & & 100 \\
\hline
\end{tabular}

(Source: Fertilizer Unit of Ministry of Agriculture and Cooperatives. 2062)

Table 10: Production of Fertilizers in Nepal (in metric tones)

\begin{tabular}{|l|l|l|l|}
\hline Year & $\mathbf{2 0 : 2 0}$ & $\mathbf{2 0 : 2 0 : 1 0}$ & Total \\
\hline $2000 / 01$ & 10253 & 310 & 10576 \\
\hline $2001 / 02$ & 10610 & 399.5 & 11114 \\
\hline $2002 / 03$ & 3578 & & 3799 \\
\hline $2003 / 04$ & 14289 & & 14958 \\
\hline $2004 / 05$ & 11064 & & 13543 \\
\hline
\end{tabular}

(Source: Fertilizer Unit of Ministry of Agriculture and Cooperatives. 2062)

ration (AIC) , Private Institutions and also donated/granted by the Government of Japan called as 2KR (Two Kenny Round). In the past till1998/99 highest quantity of fertilizers were imported by Public Institution i.e. AIC however its share decreased since then. In the year 2003/04, AIC imported only $7 \%$ whereas private institutions imported $83 \%$ and $2 \mathrm{KR}$ imported $10 \%$. But again the import by AIC increased to $21 \%$ in the year 2004/05. The import of fertilizers was highest in 1998/ 99 which amounted to 219038 Metric ton and since then it decreased although there showed fluctuations. The distribution of fertilizers was increase from 1997/98 and reached highest in the year 2002/03 and since then it started decreasing. Similarly, the fertilizer consumption was the highest in the year 1994/95 which was $30.4 \mathrm{~kg} / \mathrm{ha}$ which declined since then and showed fluctuation. The fertilizer consumption is regularly decreasing in the recent years from the year 2002/03.

\section{CONCLUSION:}

In Nepal, nine Major Pesticides groups with seven subgroups of Insecticides are in use .The pesticide use amounts to $142 \mathrm{~g} /$ ha which is low compared to other counties. Similarly, seven types of fertilizers are being used in Nepal viz. Urea, Diammonium Phosphate (DAP), Murate of Potash (MOP), Ammonium Sulphate (AS), Single Super Phosphate (SSP), Ammonium Phosphate Sulphate (APS) and NPK in Nepal and the its consumption is $19.65 \mathrm{~kg} / \mathrm{ha}$ in $204 / 05$.

\section{ACKNOWLEDGEMENT:}

We are very grateful to Ministry of agriculture and Cooperatives for providing data related to the study.

\section{REFERENCES:}

Diwakar, J. 2007. Major Pesticides and Fertilizers Used in Nepal, a case study submitted to Central Department of Environmental Science, Kirtipur, Nepal.

Fertilizer Unit of Ministry of Agriculture and Cooperatives. 2062. Demand, Import and Distribution of Fertilizers since Deregulation (unpublished), Nepal Government.

Miller, J.T. 1996 Living in the Environment, Principles, Connections, and Solutions, $12^{\text {th }}$ edition, Wadsworth Publishing Company, An International Thomas Publishing Company, Belmont, USA.

Palikhe, B. R. 2006. Appropriate Integrated Pest and Pesticide Management System, Proceedings of Fourth National Conference of Science and Technology. March 23-26, 2004. Nepal Academy of Science and Technology, Khumultar, Lalitpur, Nepal. (1) 550-555.

Pesticides registration and management section of Ministry of Agriculture and Cooperatives. 2062. Introduction of Pesticides registration and management, achievement, and pesticides management guidelines. Nepal Government. pp. 79.

PPD. 2003. Annual Progress Report. 